\title{
Perkembangan Akuntansi Thailand dan Analisis Shenanigans pada Perusahaan Group Lease
}

\author{
Natalis Christian ${ }^{1}$, Veronica ${ }^{2}$, Lisa Lim3 ${ }^{*}$ \\ Universitas Internasional Batam ${ }^{1,2,3}$ \\ natalis.christian@uib.ac.id, 1842081.veronica@uib.edu, 1842078.lisa@uib.edu
}

*Penulis Korespondensi

Dikirim : 21 Juni 2021

Diterima : 17 Juli 2021

Dipublikasikan : 1 Agustus 2021

\begin{abstract}
Thailand is ASEAN country that managed to escape colonialism. However, like Anglo American countries, the country's accounting system emphasizes the transparency and information needs of investors. After the 1997 financial crisis, Thailand reformed to improve government cooperation and investment competition. Thailand's economy is recovering rapidly and is showing good growth. Due to economic growth, the poverty rate also fell. There are types of Thai state accounting standards namely International Financial reporting standards (IFRS) and Thai accounting standards (IFAC). The current development of accounting has to do with manipulation in the company's financial statements. A financial shenanigan is a false statement about the status and financial performance in a financial statement. Financial fraud can be a minor violation, such as through the free interpretation of accounting principles where it has 7 categories of shenanigans. In this discussion, the author presented an analysis of accounting progress in Indonesia with Thailand and analyzed 7 shenanigans to manipulate financial statements in Thai state companies. In this article take the company that makes the selected object that is the Group Lease company. This Group Lease is one of the companies originating from Thailand which is engaged in financing services. This method of research shows that group lease companies manipulate shenanigans 2.
\end{abstract}

Keywords: Accounting Progress; Financial Shenanigans; Indonesia;Manipulation;Thailand

\section{PENDAHULUAN}

Kecurangan akuntansi di kawasan Asia Pasifik cukup tinggi (Sakti et al., 2020), berdasarkan survei yang dilakukan oleh Association of Certified Fraud Examiners (ACFE) pada laporan tahun 2020 menunjukkan kasus kecurangan laporan keuangan di Asia Pasifik berada di urutan ketiga dari 8 bagian negara yaitu sebanyak 198 kasus yang menyebabkan rata-rata kerugian mencapai US\$1.988.000 (ACFE, 2020a). Di bagian Asia Pasifik sendiri menunjukkan kasus tertinggi diperoleh dari Indonesia yaitu sebanyak 36 kasus, sedangkan

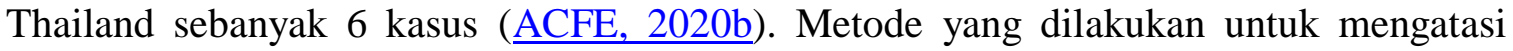
kecurangan akuntansi yaitu dengan dilakukan audit oleh pihak eksternal (ACFE, 2020a, 2020b). Menurut Kusuma et al. (2019), kecurangan dalam akuntansi sedang menjadi pembahasan utama dalam setiap pemberitaan di seluruh negara termasuk Indonesia. Kecurangan ini dapat menyebabkan turunnya akuntabilitas manajemen dan menyebabkan biaya monitoring perusahaan meningkat.

Berdasarkan survei yang dilakukan oleh PricewaterhouseCoopers (PwC) yang dilakukan pada tahun 2018 di wilayah ASEAN yang meliputi 6 negara yaitu Malaysia, Philipina, Thailand, Singapura, Vietnam, dan Indonesia. Persentase kecurangan laporan keuangan pada tahun 2018 menunjukkan hasil bahwa negara Indonesia berada di posisi ketiga setelah Philipina dan Vietnam, kemudian disusul oleh Thailand, Malaysia dan Singapura (PWC, 2018). Kecurangan pada akuntansi dapat dikelompokkan menjadi 3 macam yaitu penyalahgunaan aktiva, kecurangan dalam laporan keuangan serta korupsi 
(ACFE, 2020a; Nita \& Supadmi, 2019; PWC, 2018). Setiap tahun terdapat kasus-kasus kecurangan yang menjadi permasalahan. Kecurangan pada laporan keuangan terjadi karena adanya dorongan atau motivasi dari berbagai pihak baik internal maupun eksternal agar laporan yang disajikan terlihat lebih menarik investor ataupun calon investor (Septriyani \& Handayani, 2018). Sehingga dapat menyebabkan investor salah dalam mengambil keputusan investasinya, contohnya seperti kasus Group Lease yang melakukan manipulasi harga saham perusahaannya, akibat dari kecurangannya menyebabkan Group Lease harus membayar denda yang sangaat besar ke pemerintah (Equity, 2017).

Artikel ini membahas tentang perkembangan akuntansi di negara Thailand dan Indonesia, hingga meliputi perbandingan akuntansi kedua negara. Artikel ini juga menganalisis kasus kecurangan yang terjadi pada perusahaan Group Lease yang merupakan salah satu perusahaan publik di Bursa Efek Thailand dengan mengkaji kasus berdasarkan Shenanigans satu hingga tujuh.

\section{Laporan Keuangan}

\section{STUDI LITERATUR}

Laporan keuangan sebagai salah satu sumber dalam menganalisis kinerja suatu perusahaan, yang dapat menjadi acuan dalam pengambilan keputusan. Laporan keuangan harus disajikan sesuai standar akuntansi yang berlaku (Udayana, 2017). Menurut (Christian et al. (2021) standar akuntansi yang berlaku meliputi prinsip dan praktik dalam memandu transaksi keuangan, dengan tujuan menentukan cara dalam mengakui, mengukur, menyaji dan syarat suatu transaksi. Laporan keuangan menyajikan informasi yang dapat dibandingkan, mudah dimengerti dan relevan yang menjadikan laporan keuangan dapat digunakan secara maksimal (Rusmana \& Tanjung, 2020)

\section{Financial Shenanigans}

Financial shenanigans sebagai suatu tindakan yang dilakukan secara sengaja oleh manajemen perusahaan dengan tujuan untuk memanipulasi pengguna laporan keuangan dalam menganalisis kondisi dan kinerja perusahaan (Schilit, 1968). Dalam mendeteksi praktik shenanigans, dapat dianalisa melalui laporan posisi keuangan, laporan laba rugi, dan laporan arus kas. Menurut Rieantiari \& Hermawan (2020) financial shenanigans mungkin tidak dapat ditemukan dalam bentuk angka pada laporan keuangan. Oleh karena itu, para pengguna laporan keuangan perlu lebih teliti untuk membaca dan menganalisis isi dalam laporan keuangan.

Menurut Natalis et al. (2021) teknik financial shenanigans dapat dilakukan lebih dari satu kali yang dapat menyebabkan kerugian bagi manajemen, perusahaan dan berdampak bagi masyarakat. Financial shenanigans dapat memanipulasi investor, karena keputusan yang diambil investor melalui laporan keuangan yang disajikan.

\section{METODE}

Penelitian ini melakukan analisa perkembangan akuntansi Negara Indonesia dan Thailand serta analisa financial shenanigans pada perusahaan Group Lease. Data yang dianalisa yaitu laporan tahunan dan keuangan dari Group Lease tahun 2012-2017 yang merupakan data sekunder dari website perusahaan. Group Lease Finance bergerak dibidang keuangan yang tercatat di bursa saham Thailand. Perusahaan menyediakan jasa pembiayaan di Asia Tenggara yang pada tahun 2016 grup melakukan ekspansi bisnis di Indonesia.

Penelitian ini menggunakan metode pengumpulan data dan informasi terkait penelitian yaitu dengan menggunakan penelitian kualitatif dan kuantitatif. Space (2014) menjelaskan bahwa penelitian kualitatif diartikan sebagai model penelitian dimana informasi yang dikumpulkan tidak diperoleh melalui metode statistik atau bentuk digital. Jenis survei ini biasanya ditujukan untuk memberikan penjelasan mendalam tentang objek penelitian. Metode penelitian didasarkan pada 
fakta untuk membuat deskripsi yang sistematis (Wahidmurni, 2017). Secara kualititatif, penelitian ini mendeskripsikan perbedaan perkembangan akuntansi antara Negara Indonesia dan Thailand.

Sedangkan penelitian kuantitatif merupakan suatu penelitian yang menggunakan data angka dan statistik untuk analisis analisis. Penelitian kuantitatif adalah proses pengumpulan, analisis, interpretasi, dan pencatatan hasil. Metode kuantitatif biasanya menggunakan data yang diukur secara obyektif dari kejadian aktual untuk melakukan penelitian (Wahidmurni, 2017). Secara kuantitatif, penelitian ini menganalisa data laporan tahunan dan keuangan Group Lease tahun 2012 hingga 2017 yang dikaitkan pada financial shenanigans.

\section{HASIL DAN PEMBAHASAN}

\section{Sejarah Perkembangan Akuntansi di Thailand}

Thailand adalah negara di Asia Tenggara yang tidak mengalami penjajahan. Sistem akuntansi yang berlaku membuktikan nilai transparansi dan informasi yang dibutuhkan oleh investor di Inggris dan Amerika Serikat. Standar akuntansi Thailand dikeluarkan oleh Asosiasi Akuntan dan Auditor Thailand (ICAAT), yang berdiri tahun 1948 dan dimiliki oleh Asosiasi Akuntan dan Akuntan Thailand (ICAAT). Namun, perlu terlebih dahulu mendapatkan persetujuan dari Kementerian Perdagangan sebelum melakukan operasi ini. Sejauh ini, ICAAT telah menyetujui 21 IFRS. Komisi Sekuritas dan Bursa Thailand mewajibkan semua perusahaan yang ada di Bursa Efek Thailand diaudit oleh auditor. Thailand (Thai GAAP) prinsip akuntansi yang berlaku umum didasarkan pada IAS dan Indonesia GAAP. Standar Akuntansi AS hanya menggunakan beberapa Standar Akuntansi Thailand (TASS), seperti restrukturisasi pinjaman bermasalah, reksa dana, akuntansi untuk kewajiban dan kredit macet, dan pencatatan pendapatan real estat. Federasi Profesional Akuntansi (TPI) mempunyai rencana untuk sepenuhnya mengangkat IFRS menjadi prinsip akuntansi Thailand pada tahun 2011 untuk memungkinkan perdagangan aktif (SET 50) dari 50 perusahaan yang terdaftar di Bursa Efek Thailand. Oleh karena itu, SAK SET 100 direncanakan akan diambil alih sepenuhnya pada tahun 2013.Perusahaan terbuka lainnya dan perusahaan yang terdaftar di Pasar Investasi Alternatif (MAI) harus menerima sepenuhnya SAK 2015. IAS dan SAK berlaku untuk semua emiten tanpa batasan dan diterbitkan pada batch pertama tahun 2009(IFRS, 2008). Untuk emiten yang tidak terdaftar, TPI mempunyai rencana melaksanakan TASS dan TFRS, yang sesuai dengan IAS dan SAK versi 2006 (IFRS, 2006) dan akan dilaksanakan pada 2011. Namun, FAP dapat memanifestasikan pesan pengecualian untuk TASS dan TFRS tertentu. Untuk perusahaan yang tidak terdaftar untuk diterapkan (HikmaningTiyas, 2020).

Ada beberapa faktor penyebab yang mempengaruhi perkembangan akuntan publik di Thailand. Perkembangan akuntansi saat ini di Thailand mempengaruhi sumber dana, sumber hukum, perpajakan, ikatan politik \& ekonomi, inflasi \& tingkat perekonomian, peningkatan pendidikan, dan budaya yang akan dijelaskan lebih terperinci dibawah ini:

\section{Sumber Dana}

Sumber Dana Thailand sangat bergantung pada ekspor. Nilai ekspor Thailand menyumbang sekitar enam puluh persen dari Produk Domestik Bruto. Pemulihan Thailand dari krisis keuangan Asia dari 1997 hingga 1998 sangat bergantung pada permintaan eksternal dari Amerika Serikat dan pasar luar negeri lainnya. Sebagian besar angkatan kerja di Thailand merupakan pekerja dibidang pertanian khususnya pertanian padi. Angka angkatan dibidang pertanian mencapai $60 \%$ dari seluruh pekerja di Thailand. Thailand juga merupakan salah satu pengekspor pariwisata terpenting di pasar dunia. Hasil yang diproduksi dalam jumlah banyak adalah ikan dan hasil pertanian lainnya. Jenis pertanian lainnya adalah ubi kayu, getah, biji-bijian dan gula. Ekspor makanan olahan seperti tuna kaleng, nanas dan makanan beku juga mengalami peningkatan (Rahmawati, 2013). Ekspor 
beras dan makanan lainnya ke Thailand dapat meningkatkan pendapatan nasional Thailand. Ketika pendapatan meningkat, itu bisa digunakan sebagai dana nasional. Semakin banyak pendapatan yang dihasilkan, semakin banyak dana atau pengeluaran yang dapat dibelanjakan Thailand (Rahmawati, 2013).

\section{Sumber Hukum}

Penegak aturan terbaru Thailand merupakan Pangeran Rabi Ratchaburi, yang sudah memainkan kiprah krusial pada penerapan sistem manajemen peradilan terbaru. Penyusunan undang-undang sipil \& komersial dimulai dalam kala pemerintahan Raja Rama V \& terselesaikan dalam masa pemerintahan Raja Rama VII (HikmaningTiyas, 2020). Revolusi tahun 1932 mengubah bentuk pemerintahan di Thailand dari monarki absolut menjadi monarki konstitusional, yang berdampak signifikan pada sistem hukum dan peradilan Thailand. Konstitusi memberikan keadilan bagi peradilan. Hakim menjalankan tugasnya atas nama raja dan memastikan bahwa kasus tersebut ditinjau secara independen sesuai dengan hukum yang berlaku (HikmaningTiyas, 2020).

\section{Perpajakan}

Informasi pajak Thailand: pajak penghasilan umum, cara menghitung, kapan harus membayar pajak, tunjangan. Siapapun, apakah mereka orang asing atau orang Thailand yang bekerja atau mempunyai PKP di Thailand, harus mengajukan nomor pajak yang dikeluarkan oleh Kementerian Keuangan. Saat menunjukkan KTP atau paspor Thailand di luar negeri dan menyatakan bahwa nomor tersebut diperlukan, tarif pajak untuk usaha kecil dan menengah serta kemitraan resmi lebih rendah (HikmaningTiyas, 2020). Dalam hal ini, modal badan hukum tidak melebihi 5 juta baht. Perpajakan di Thailand adalah sebagai berikut laba bersih dalam periode pelaporan $<150.000$ baht tidak dipungut pajak, laba bersih dalam periode pelaporan $>150.000$ baht tetapi $<1$ juta baht tarifnya adalah $15 \%$, laba bersih dalam periode pelaporan melebihi 1 juta baht sejak 2012 sampai 1 Januari 2013 tarif pajak adalah 23\%, dan mulai 1 Januari 2013 tarif pajak adalah 20\%. Departemen pajak utama ada di Bangkok, tetapi ada cabang dari Kementerian Keuangan Thailand. Kantor pusat juga memiliki staf berbahasa Inggris yang dapat membantu dalam dokumentasi.

\section{Ikatan Politik dan Ekonomi}

Politik Thailand saat ini diatur oleh monarki konstitusional. Perdana menteri telah menjadi kepala pemerintahan dan kepala negara kerajaan selama beberapa generasi. Peradilan tidak tunduk pada yurisdiksi administratif dan legislatif dari pemerintah. Baik Kerajaan Thailand dan Kerajaan Siam terakhir berada di bawah kendali penuh raja. Setelah revolusi birokrasi demokratis yang berpusat pada militer Barat pada tahun 1932, Negara ini secara resmi menjadi monarki konstitusional, dengan perdana menteri sebagai kepala pemerintahan. Menyusun konstitusi tertulis pertama. Tapi politik telah menjadi medan pertempuran antara faksi elit lama dan baru, birokrat dan jenderal. Asosiasi terjadi dari waktu ke waktu, dan negara biasanya memiliki sistem militer yang berbeda. Aturan dan konstitusi mencerminkan tingkat ketidakstabilan politik yang tinggi. Setelah kudeta berhasil, tentara mencabut konstitusi saat ini. Negosiasi antara politisi, influencer, dan jenderal saat ini telah menjadi faktor penting dalam memulihkan stabilitas politik (Hikmaning Tiyas, 2020).

\section{Inflasi}

Indeks tarif konsumen naik 0,22 ringgit di bulan Maret di bulan sebelumnya, dan naik hampir 0,23\% di bulan Februari. Menurut data Kementerian Perdagangan, alasan kenaikan harga pada Maret lalu adalah kenaikan harga makanan, minuman ringan, dan 
transportasi. Tingkat inflasi tahunan turun dari 2,0\% pada Februari menjadi 2,1\% pada Maret, sehingga harga konsumen inti tidak termasuk energi dan makanan segar turun dari 0,27\% pada Februari menjadi 0,08\% pada Maret, sejalan dengan ekspektasi pasar. Selain itu, tingkat inflasi inti tahunan naik menjadi 1,3\% (Februari: 1,2\%). Proyek ini masih dalam kisaran target 0,5\% hingga 3,0\% yang ditetapkan bank sentral. Bank of Thailand memperkirakan rata-rata tingkat inflasi pada tahun 2014 sebesar 2,4\%. Konsensus ahli FocusEconomics memperkirakan, rata-rata tingkat inflasi pada tahun 2014 sebesar 2,8\%, lebih rendah $0,1 \%$ dibandingkan bulan sebelumnya. Pada tahun 2015, rata-rata inflasi anggota kelompok adalah 3,1\% (HikmaningTiyas, 2020).

\section{Tingkat Perkembangan Ekonomi}

Pada tahun 2010, ekonomi Thailand akan tumbuh lebih dari 7\% tahun ini, tetapi meskipun mengalami kekerasan dan bencana selama bertahun-tahun, perekonomian tersebut melambat pada tahun 2011. Faktor-faktor yang menopang perekonomian Thailand adalah pertanian (beras, tapioka, jagung, tebu, karet, kedelai, dan kelapa), pertambangan (timah, emas, minyak dan gas, tembaga, timbal, bijih besi, dan tungsten), industri (pengolahan beras, pengolahan karet, semen, tekstil, pemintalan dan berbagai jenis minyak, industri otomotif dan perakitan komponen elektronik), pariwisata (tempat wisata yang terkenal adalah Pantai Panoramaindah di Pattaya dan Chiang Mai (Pegunungan Utara) di pantai Teluk Thailand)

\section{Tingkat Pendidikan}

Dalam pertemuan dengan Pakar Pendidikan (atdik), ia menggabungkan rencana kerja dan kurikulum sekolah luar negeri Indonesia di Bangkok (SILN) dan berbicara tentang sistem pendidikan Thailand. Sistem pendidikan Thailand dibagi menjadi tiga bidang: Pendidikan formal, pendidikan non formal dan pendidikan informal Sistem pendidikan formal meliputi pendidikan dasar dan pendidikan tinggi. Sistem pendidikan nonformal meliputi: kursus sertifikasi profesi, kursus singkat untuk sekolah kejuruan dan pemangku kepentingan. Pendidikan wajib di Thailand adalah 9 tahun pendidikan wajib. Tidak perlu mendaftar ulang untuk kelas 7 sampai 12 di kompleks sekolah, tetapi otomatis akan melanjutkan belajar di sekolah tersebut. UN Thailand (PBB) diselenggarakan oleh Kantor Ujian Mengajar dari Komisi Pendidikan Dasar, yang menggunakan Ujian Pendidikan Nasional (O-net) biasa. Persyaratan Kelas 3, 6, 9 dan 12. Ada 8 topik yang terkait dengan UNED, yaitu: Thailand Language, Math, Science, Social, Health \& Physical Education, Religion, Foreign Language, Art, Career dan Technology.

\section{Budaya}

Budaya Thailand adalah kombinasi pengaruh budaya prasejarah dari Thailand kuno, Cina, Kamboja dan tetangganya Asia Tenggara, dan menyatukan kepercayaan budaya dan karakteristik masyarakat adat di wilayah yang disebut sebagai Thailand modern. Ini terutama dipengaruhi oleh animisme, Hinduisme, Budha, dan migrasi berikutnya dari Cina dan India Selatan.

\section{Landasan Hukum Akuntansi Thailand}

Saat ini, layanan yang disediakan oleh para profesional akuntansi diatur oleh undang-undang yang berkaitan dengan pembukuan berdasarkan Undang-Undang Akuntansi.B.E. 2543 (2000). Di Thailand, berdasarkan hukum, akuntan digambarkan sebagai pembukuan. Pembukuan didefinisikan sebagai "orang yang bertanggung jawab atas pembukuan, orang yang memiliki tugas untuk menyimpan akun, orang yang memiliki 
tugas untuk menyimpan akun" Pembukuan diatur oleh Departemen Pengembangan Usaha (DBD), Kementerian Perdagangan (Aseancpa, 2020).

Profesi akuntansi yang mencakup profesi dalam pembukuan, audit, akuntansi manajerial, sistem akuntansi, akuntansi pajak, pendidikan akuntansi dan teknologi, atau layanan akuntansi lainnya yang ditentukan oleh peraturan menteri diatur oleh UndangUndang Profesi Akuntansi B.E. 2547 (2004) ("Undang-Undang") dan diatur sendiri secara profesional oleh Federasi Profesi Akuntansi (TFAC). Berdasarkan undang-undang, hanya akuntan publik bersertifikat yang diizinkan untuk mengajukan lisensi auditor dari TFAC (Aseancpa, 2020).

Namun, berdasarkan Undang-Undang ini, Komisi Pengawas Akuntansi Profesional, otoritas, telah dibentuk untuk mengawasi semua kegiatan TFAC sesuai dengan Undang-Undang.UU menetapkan kewenangan, peran dan tujuan dalam bidang-bidang berikut: federasi profesi akuntansi, anggota federasi profesi akuntansi, komite federasi profesi akuntansi, komite akuntansi standar-pengaturan, pengawasan profesi auditing, pengawasan profesi pembukuan, kode etik profesi akuntansi, pengawasan terhadap profesi akuntansi, dan hukuman.

\section{Landasan Hukum Akuntansi Indonesia}

Sesuai dengan tujuan IAI Indonesia mengaudit akuntan publik, maka ketentuan UU No. 34 Tahun 1954 dilaksanakan (Peraturan tentang Penerapan Peraturan Menteri Keuangan Nomor 25 / PMK).Tanggal yang relevan adalah 01/2014 dari Daftar Akuntansi Nasional pada 3 Februari 2014. Menurut FMK, akuntan adalah pendaftar di Daftar Akuntan Nasional (SRB) yang diselenggarakan oleh Menteri Keuangan.Untuk memasuki Biro Registrasi Akuntansi Nasional, Orang tersebut harus memenuhi persyaratan berikut: dia telah menyelesaikan pelatihan profesional akuntansi atau lulus ujian auditor, dan memiliki pengalaman di bidang akuntansi profesional. Dan menjadi anggota Asosiasi Auditor Profesional (IAI, 2020b).

PMK juga mencontohkan: pelatihan akuntan profesional meliputi kuliah dan ujian bagi akuntan profesional. Selain itu, Peraturan Menteri Pendidikan dan Kebudayaan Republik Indonesia Nomor 153 Tahun 2014, "Program Pelatihan Profesi Yang Berlaku untuk Akuntan", mengatur penyelenggaraan IAI Program Pelatihan Profesi Akuntan (PPAk) perguruan tinggi dan organisasi koperasi. Keputusan Menteri Pendidikan dan Kebudayaan yang disahkan pada tanggal 17 Oktober 2014 terkait dengan ketentuan Pasal 14 Ayat 2 Peraturan Pemerintah Republik Indonesia Nomor 4 tentang Pendidikan Tinggi dan Penyelenggaraan Pendidikan Tinggi Tahun 2014. Setelah lulus semua ujian akuntansi, dapatkan gelar akuntansi dan dapatkan sertifikat akuntansi profesional. Tes kemampuan akuntansi adalah ujian sertifikasi akuntan profesional yang diadakan oleh IAI (IAI, 2020b).

\section{Organisasi Profesi Akuntansi Thailand}

Sistem akuntansi Thailand menghargai transparansi dan kebutuhan informasi investor Inggris dan Amerika. Pasca krisis keuangan 1997, Thailand melakukan reformasi untuk meningkatkan kerja sama dengan pemerintah dan meningkatkan daya saing investasi. Perekonomian Thailand pulih dengan cepat dan tumbuh dengan kuat. Ketika ekonomi tumbuh, itu juga menurun (Dianitafairtale, 2017).

Standar akuntansi yang dikeluarkan oleh ICAAT dirumuskan pada tahun 1948. Namun, Standar Akuntansi Thailand harus disetujui dan dikeluarkan oleh Kementerian Keuangan sebelum perusahaan dapat menerapkannya. ICAAT telah mengadopsi 21 dari semua standar IAS. Bursa Efek Thailand mengharuskan semua perusahaan yang terdaftar di SET (Bursa Efek Thailand) diaudit oleh auditor eksternal independen. Selain itu, emiten harus memenuhi banyak persyaratan investor. Selain itu, juga telah diputuskan untuk 
mengalihkan pengawasan terhadap emiten yang sebelumnya dilakukan oleh Menteri Keuangan kepada Securities and Exchange Commission Thailand, yang akan mengarah pada pengawasan organisasi dan sanksi hukum terhadap perusahaan yang telah tercatat di bursa (Dianitafairtale, 2017).

GAAP Thailand yang diterima secara umum didasarkan pada IFRS dan TFRS. Ada sangat sedikit Standar Akuntansi Thailand (TASS), Akuntansi untuk kredit macet, kredit macet, kredit macet dan pendapatan bisnis tetap menurut US-GAAP. Federasi Akuntan Profesional (TPI) berencana untuk sepenuhnya mengadopsi IFRS 2011 sebagai prinsip akuntansi Thailand untuk memungkinkan perdagangan aktif (SET 50) dari 50 perusahaan yang terdaftar di Bursa Efek Thailand. Setelah IFRS diadopsi sepenuhnya dalam SET 100, emiten dan emiten lain yang terdaftar di Pasar Investasi Alternatif (MAI) harus mendapatkan SAK lengkap untuk tahun 2015 (Dianitafairtale, 2017).

Seperti disebutkan sebelumnya, IAS dan SAK semuanya telah diterapkan ke semua perusahaan terbuka, dan menjadi grosir pertama pada tahun 2009 (IFRS 2008). Untuk emiten yang tidak terdaftar, TPI $b$ berencana menerbitkan TASS dan TFRS sesuai dengan IFRS dan IFRS 2006 (IFRS, 2006), yang akan dilaksanakan pada tahun 2011. Namun, FAP dapat mengeluarkan pemberitahuan yang berisi pengecualian tertentu untuk TASS dan TFRS, yang terlalu rumit untuk perusahaan yang tidak terdaftar.

Sistem Akuntansi di Thailand adalah menghormati transparansi kebutuhan informasi investor. Prinsip akuntansi Thailand saat ini adalah THAI GAPP didasarkan pada IAS dan SAK. Federasi Profesional Akuntansi (TPI) berencana untuk memperkenalkan SAK ke GAPP Thailand. Standar Akuntansi dan Pelaporan Keuangan Thailand yang diterbitkan oleh Federasi Profesional Akuntansi Thailand (FAP) sesuai dengan Standar Akuntansi Internasional (IAS) dan Standar Pelaporan Keuangan Internasional (IFRS). Thailand standards pelaporan keuangan untuk Non-Public Akuntanbel entitas-NPAEs.

\section{Organisasi Profesi Akuntansi Indonesia IAI (Ikatan Akuntan Indonesia)}

Ikatan akuntan indonesia adalah organisasi profesi yang beranggotakan seluruh akuntan Indonesia. Organisasi IAI didirikan pada tanggal 23 Desember 1957. Ikatan akuntan indonesia ini diadakan dengan tujuan untuk ujian sertifikasi profesi akuntansi serta pengembangan akuntan profesional dengan mengembangkan praktek akuntansi serta menetapkan kode etik profesi akuntansi (IAI, 2020)

\section{IAPI adalah Ikatan Akuntan Indonesia (Institut Akuntan Publik Indonesia)}

Institut akuntan publik indonesia adalah organisasi yang bertujuan untuk mengadakan ujian sertifikasi profesi akuntan punblik, menetapkan standar profesional dan etika bagi akuntan, serta menyelenggarakan dan mengaudit kursus pelatihan tentang akuntan. kualitas akuntan (IAPI, 2020).

\section{IAMI (Indonesia institute of management accountant)}

Indonesia institute of management accountant adalah Institut Akuntan Publik Indonesia, yang merupakan organisasi profesi akuntan Indonesia. IAMI didirikan pada tanggal 1 April 2008. organisasi ini didirikan dengan tujuan mengukur komptensi dalam bidang akuntansi manajemen (IAMI, 2020).

\section{IKPI (Ikatan konsultan pajak indonesia)}

Ikatan Konsultan Pajak Indonesia adalah sebuah organisasi profesi konsultan pajak. Anggotanya adalah konsultan pajak yang dapat membantu wajib pajak memenuhi kewajiban perpajakannya (IKPI, 2020). 


\section{Sertifikasi Akuntansi profesi Thailand}

Sertifikasi akuntansi profesi thailand ada terdapat beberapa sertifikasi sebagai berikut: Certified Management Accountant (CMA), Association of Chartered Accountant (ACCA) (Dianitafairtale, 2017).

\section{Sertifikasi Akuntansi profesi Indonesia}

Sertifikasi Akuntansi profesi Indonesia ada terdapat beberapa sertifikasi sebagai berikut: Certified Intern Auditor (CIA), Charter Accountant (CA), Certified Public Accountant (CPA), Certified Management Accountant (CMA) (IAI, 2020).

\section{Standar Pelaporan Laporan Keuangan Thailand}

Standar pelaporan keuangan Thailand adalah TFRS (Thailand Financial Reporting Standards) yang dikeluarkan oleh Federasi Profesi Akuntasi sehubung dengan penerapannya di Kerajaan Thailand. Standar pelaporan keuangan Thailand tidak dapat diatribusikan diluar kerajaan Thailand.

Thailand Accounting Standards (TAS) mengadopsi TFRS yang di revisi pada tahun 2017 berdasarkan volume terikat Standar Pelaporan Keuangan Internasional (IFRS) yang efektif digunakan negara Thailand untuk periode pelaporan tahunan yang dimulai pada 1 januari 2018 (IFAC, 2017).

\section{Standar Pelaporan Laporan Keuangan Indonesia}

Pernyataan Standar Akuntansi-Standar Pelaporan Keuangan Internasional (PSAKIFRS) adalah nama lain dari standar akuntansi Indonesia yang digunakan oleh IAI (Ikatan Akuntan Indonesia) dari tahun 2012 hingga saat ini. Tujuan PSAK sama dengan SAK yang bertujuan untuk memberikan informasi yang relevan bagi pengguna gelar.

Penerapan IFRS didasarkan pada fakta bahwa Indonesia adalah anggota IFAC (International Federation of Accountants), yang menjadikan IFRS sebagai standar akuntansi. Standar akuntansi di Indonesia meliputi PSAK-IFRS (Pernyataan Standar Akuntansi Keuangan), SAK-ETAP (Standar Akuntansi Keuangan untuk Organisasi Akuntansi Non Pemerintah), PSAK-Syariah (Pernyataan Standar Akuntansi Keuangan Syariah) dan SAP (Standar Akuntansi Negara) (Dewanti, 2015).

\section{Pengukuran Akuntansi Thailand}

Pengukuran Akuntansi di Thailand menggunakan konsep Going Concern. Perusahaan dapat melanjutkan usahanya dan biaya asset harus disesuaikan dengan periode keuangan yang diharapkan memberikan keuntungan ekonomi bagi suatu perusahaan, entitas dapat memilih antara menggunakan fair value atau cost model. Selain itu, perusahaan juga menggunakan konsep Matching, prinsip akuntansi bahwa pengeluaran harus diakui pada saat pendapatan diakui, dengan tujuan menyajikan secara akurat laba bersih pada periode akuntansi (HikmaningTiyas, 2014).

\section{Pengukuran akuntansi Indonesia}

Pengukuran Akuntansi di Indonesia terdiri dari konsep Matching, prinsip akuntansi bahwa pengeluaran harus diakui pada saat pendapatan diakui dengan tujuan menyajikan secara akurat laba bersih pada periode akuntansi, penggabungan usaha menggunakan metode penyatuan kepentingan dan metode pembelian, Goodwill yang timbul akibat akuisisi diamotirasi untuk 5 tahun dan paling lama 20 tahun, jumlah nilai buku yang melampaui nilai wajarnya dibebankan ke laba, Joint venture menggunakan metode ekuitas (Siallagan, 2016). 


\section{Pengungkapan Akuntansi Thailand}

Informasi yang perlu segera untuk diungkapkan merupakan informasi yang dapat berdampak signifikan pada sekuritas perusahaan dan harga pasarnya dan infomasi yang mempengaruhi keputusan investasi terkait dengan sekuritas perusahaan dan pemegang saham (Acclime, 2021).

\section{Periodic Disclosure}

Laporan keuangan harus diserahkan ke SET dalam Bahasa Thailand dan Inggris melalui portal SET. Laporan keuangan yang tidak diaudit harus diserahkan dalam kurun waktu 30 hari sejak akhir periode akuntansi perusahaan. Laporan keuangan triwulanan yang ditinjau termasuk laporan konsolidasian harus diserahkan dalam waktu 45 hari pada akhir setiap triwulan. Laporan tahunan (audited) harus diserahkan dalam waktu tiga bulan sejak akhir periode akuntansi. Laporan tahunan harus diserahkan kepada SET dalam waktu empat bulan sejak akhir periode pembukaan dan pada saat yang sama perusahaan tercatat mendistribusikan laporan tahunan dan RUPS kepada pemegang saham.

\section{Disclosure of Material Events:}

Peristiwa penting seperti pemberitahuan pembagian deviden, penambahan model, merger dan akuisisi, perubahan struktur pemegang saham atau peristiwa penting lain yang secara signifikan mempengaruhi bisnis harus segera diungkapkan.

\section{Pengungkapan Akuntansi Indonesia}

Dalam penyajian laporan keuangan tahunan SPA 1, paragraf 70 menyatakan bahwa catatan atas laporan keuangan tahunan meliputi neraca, laporan laba rugi, laporan arus kas, dan laporan keuangan tahunan. Informasi tambahan. Catatan atas laporan keuangan mengungkapkan informasi tentang informasi dasar untuk penyusunan laporan keuangan dan kebijakan akuntansi yang dipilih untuk peristiwa atau transaksi besar, informasi yang disajikan dalam PSAK tetapi tidak disajikan di neraca, laporan laba rugi, laporan arus kan dan laporan perubahan ekuitas, informasi lain yang tidak termasuk dalam laporan keuangan tetapi diperlukan untuk penyajian yang wajar. Semakin lengkap informasi yang diungkapkan dalam catatan atas laporan keuangan maka pembaca akan semakin mengerti mengenai kinerja keuangan perusahaan (Simbolon, 2010).

\section{Masalah Akuntansi Saat Ini}

Keberadaan Organisasi Akuntan Thailand yang dikenal dengan Federasi Profesi Akuntansi (FAP) memberikan solusi akan masalah akuntansi yang terjadi di Thailand. FAP bertanggung jawab untuk mengatur profesi akuntansi di bawah pengawasan Komisi Pengaturan Profesi Akuntansi. Beberapa tujuan pendirian FAP yaitu untuk menyatukan semua akuntan profesional untuk kepentingan pengembangan profesional dan mata pencaharian. FAP juga bertanggung jawab untuk membangun sistem tinjauan jaminan kualitas bagi anggotanya.

Namun, hasil menunjukkan lemahnya kontrol organisasi. Laporan keuangan di beberapa departemen masih belum diaudit secara tepat waktu dan laporan keuangan yang diaudit tidak dapat diakses publik. Perbandingan laporan keuangan antara periode dan entitas, bersama dengan konsistensi anggaran, akuntansi, dan klasifikasi statistik fiskal adalah masalah yang sedang berlangsung (Nakmahachalasint \& Narktabtee, 2018).

Federasi Profesi Akuntansi menanggapi dan menyelidiki masalah ketidakpatuhan yang terjadi, tetapi tim penegakannya perlu diperkuat. Undang-Undang Profesi Akuntansi (S. 46) mewajibkan semua anggota FAP untuk mengikuti standar akuntansi, audit, dan etika yang berlaku. Tidak ada pengaturan untuk memantau dan menegakkan kepatuhan 
terhadap persyaratan ini secara teratur. FAP dapat merujuk masalah ketidakpatuhan ke Komite Etik yang setelah investigasi dapat memberikan sanksi kepada anggota jika mereka tidak menerapkan standar yang disyaratkan dengan benar (Rahman et al.. 2018).

Yang menjadi masalah akuntansi yaitu keberadaan FAP dan Komite Etik tidak memiliki kewenangan untuk memberikan sanksi kepada anggotanya atas pelanggaran pidana atau perdata. Dilihat dari kasus-kasus sebelumnya perlu diproses melalui sistem pengadilan, yang melibatkan prosedur yang panjang. Beberapa proses pengadilan melibatkan auditor, termasuk proses banding, sedangkan proses pengadilan dari kasus sebelumnya berlangsung setelah 10 tahun berlalu.

\section{Perbandingan Praktik Akuntansi Laporan Keuangan Thailand}

Pada Negara Thailand perusahaan harus menyimpan pembukuan dan mengikuti prosedur akuntansi sesuai dengan Kode Sipil dan Komersial, Kode Pendapatan dan Undang-Undang Akun. Dokumen dapat disiapkan dalam bahasa apa pun, asalkan terjemahan bahasa Thai dilampirkan. Laporan keuangan setiap perusahaan pada akhir tahun perlu disertifikasi oleh auditor independen terlepas dari apakah perusahaan tersebut diperdagangkan atau tidak.

Perusahaan asing perlu menyerahkan laporan keuangan kepada MOC selambatlambatnya 150 hari setelah akhir tahun anggaran. Perseroan terbatas publik harus mengungkapkan informasi berikut dalam laporan tahunan seperti nama perusahaan, lokasi kantor pusat, jenis usaha, rincian sahamyang ditempatkan dan saham yang dimiliki pada anak perusahaan (jika ada), rincian direksi mengenai benturan kepentingan dalam pelayanan kontrak yang dibuat oleh perusahaan selama setiap tahun buku dan kepemilikan sahamnya di perusahaan atau di anak perusahaan dan setiap perubahan selama tahun tersebut (Acclime, 2021).

\section{Perbandingan Praktik Akuntansi Laporan Keuangan Indonesia}

Neraca disajikan ke dalam akun dengan kewajiban yang terdiri dari modal dan hutang tetap. Akun untung dan rugi memprioritaskan penyimpanan produksi global dan memungkinkan pilihan klasifikasi biaya baik berdasarkan sifat atau fungsi. Berdasarkan pasal 68 ayat 1 UU No 40 tahun 2007 tentang Perseroan Terbatas, ada syarat bagi perusahaan untuk wajib menyiapkan laporan keuangan yang sudah diaudit akuntan publik jika perusahaan menghimpun dana dari masyarakat, perusahaan terbuka, persero, perusahaan yang memiliki aset atau peredaran usaha paling sedikit Rp 50 miliyar, atau perusahaan perusahaan menerbitkan surat pengakuan hutang.

Untuk keperluan perpajakan, perusahaan penanaman modal asing (PMA), bentuk usaha tetap, entitas tertentu dengan afiliasi asing dan perusahaan yang menyusun laporan keuangan dengan menggunakan dolar AS sebagai mata uang fungsional dapat mempertahankan bahasa Inggris dan pembukuan dolar AS, dengan ketentuan persetujuan dari Kementerian Keuangan ditetapkan diperoleh.

\section{Metode dalam mendeteksi kecurangan dalam laporan keuangan}

Tujuan utama dalam mendeteksi kecurangan pada laporan keuangan yaitu menciptakan perusahaan yang sehat dan guna untuk meminimalisir kerugian akibat kecurangan yang terjadi. Menurut penelitian (Mardianto \& Tiono, 2019) fraud triangle dapat menjelaskan pengaruh terjadinya kecurangan pada laporan keuangan melalui tekanan (pressure), kesempatan (opportunity), dan rasionalisasi (rationalization). Menurut Ratnawati et al. (2016) Teknik pendeteksian kecurangan dapat dilakukan dengan 2 (dua) cara yaitu titik kritis auditing (CPA) dan BPA yang pemeriksaannya melalui catatan akuntansi. 
Berdasarkan penelitian Wahyuni (2019) pemeriksaan yang dilakukan oleh kantor akuntan public (KAP) berguna dalam mendeteksi atau meminimalisir kecurangan dalam laporan keuangan seperti memastikan pengendalian internal yang dibuat oleh manajemen telah dijalankan. Pemeriksaan ini dilakukan guna untuk mengidentidikasi dan mencegah kecurangan (fraud).

\section{Faktor pendorong Financial Shenanigans Internal kontrol}

Perusahaan yang memiliki internal kontrol yang efektif mulai dari lingkungan, struktur organisasi, kebijakan, dan standar operasional prosedur akan mengurangi tindakan kecurangan terjadi didalam perusahaan. Pola pikir untuk melakukan kejahatan akan meningkat jika suatu perusahaan memiliki pengendalian lemah terhadap perlindungan aset (Schilit, 2010). Selain itu, pengendalian dan pengawasan yang baik juga akan mengurangi risiko penipuan laporan keuangan.

\section{Pengungkapan akuntansi}

Kurangnya pengungkapan akuntansi yang mencerminkan kondisi perusahaan sebenarnya. Manajemen tidak menyajikan informasi yang sesungguhnya dihadapi perusahaan kepada para pemangku kepentingan seperti adanya kesulitan dalam keuangan, adanya ketidakpastian hutang kontigensi (Salim et al., 2021). Manajemen menggunakan trik akuntansi yang dinilai memiliki kemungkinan kecil tertangkap misalnya memainkan laba penghasilan dalam pajak (Schilit, 2010).

\section{Tekanan}

Kondisi keuangan dan profitabilitas perusahaan yang tidak stabil yang diakibatkan oleh kondisi pasar ekonomi merupakan salah satu faktor pendorong penipuan (Schilit, 2010). Tekanan luar seperti memenuhi kewajiban menjadi faktor yang mendorong manajemen melakukan manipulasi keuangan agar tetap menarik para investor. Perusahaan yang memiliki kinerja buruk yang berada dibawah rata-rata industri memiliki risiko tinggi melakukan manipulasi keuangan (Nugraheni \& Triatmoko, 2017).

\section{Analisis Financial shenanigans pada Group Lease Shenanigans 2}

Permasalahan yang terjadi di Group Lease adalah memanipulasi penambahan pendapatan melalui related party loans dan shell company, terjadi pengurangan provisi pinjaman yang sangat besar, CEO Group Lease saat itu, Mitsuji Konoshita pernah memiliki catatan pemanipulasian harga saham di perusahaan Wedge Holdings dan pada April 2017 didenda besar oleh regulator Jepang (Anonymous Equity, 2017).

Pada tahun 2015 sampai 2016, harga saham Group Lease naik hingga 1.100\%. Puncaknya adalah Desember 2016 yaitu sebesar 68,2 THB. Namun, Maret 2017 harga saham turun hampir 80\%. Merosotnya harga saham Maret 2017, disebabkan oleh publikasi laporan audit (Nama auditor : EY) yang menandai banyak masalah seperti pinjaman berbunga tinggi yang mencurigakan yang pendapatan bunganya sebesar $40 \%$ dari pendapatan setahun serta pembelian $30 \%$ saham pada perusahaan di Sri Lanka terjual dengan harga premi lebih besar $120 \%$ dari harga pasar yang diperdagangkan saat itu (Anonymous Equity, 2017). 


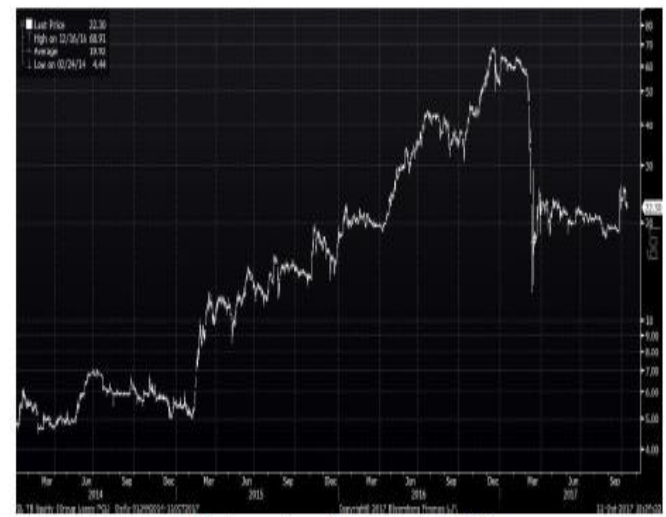

Gambä 1. Grafik Harga Saham

Sumber : (Bloomberg, 2017)

Alasan utama pendapatan dan laba Group Leasedapat lebih tinggi pada tahun 2016 adalah pinjaman besar kepada dua kelompok pemegang saham di Singapura dan Siprus, yang menghasilkan pendapatan bunga sebesar THB485 juta (Singapura) dan THB525 juta (Siprus). Jumlah ini memberi kontribusi sebesar $40 \%$ dari laba bersih konsolidasi. Group Lease berulang kali menyatakan bahwa peminjamnya di Singapura dan Siprus bukanlah related party Group Lease. Namun, setelah dilakukan pemeriksaan rinci terhadap Group Lease dan APF Group (Induk perusahaan Group lease), ditemukan bahwa peminjam Singapura dan Siprus termasuk sebagai pihak terkait Group Lease. Muncul kecurigaan bahwa Group Lease sebenarnya memainkan "Round Tripping" dimana pendapatan bunga dari peminjam Singapura sebenarnya bukan pendapatan bunga sama sekali. Kasus round tripping ini mirip dengan kasus manipulasi harga saham yang terjadi pada Wedge Holdings yang dilakukan oleh Mitsuji Konoshita (Berthelsen, 2017).

Salah satu peminjam dari Singapura Tep Rithivit merupakan teman Konoshita. Tep Rithivit juga mengontrol peminjam-peminjam dari Singapura. Sehingga hubungan seperti ini sangat memungkinkan untuk terjadi sebuah permainan. Sedangkan untuk Siprus memiliki 50\% sahamdari bisnis toko roti yang dipegang oleh dua perusahaan (A.M.N. Bakeries Ltd. dan Margarita N.M. Retail Ltd.) yang memiliki merek "Margarita Bakeries". Dalam pernyataannya saat itu, Group Lease mengklaim sedang memasuki skema kolaborasi dengan Margarita Bakeries di Siprus dan Myanmar. Jika Adalene Ltd adalah kendaraan yang digunakan Group Lease untuk berkolaborasi dengan Margarita Bakeries, maka itu akan membuat Adalene Ltd (peminjam terbesar di Siprus) menjadi pihak terkait Group Lease (Equity, 2017).

Bunga pinjaman bank yang ditawarkan sangat tinggi dan akan sangat aneh bila perusahaan yang sehat (tidak melakukan permainan penipuan) setuju akan bunga pinjaman yang tinggi ini. Namun Group Lease mengklaim bahwa itu adalah grup perusahaan Jepang (Kuga Corp dan perusahaan terkait lainnya) yang mengontrol peminjam Singapura, padahal peminjam Singapura dikendalikan oleh Tep Rithivit, yang memiliki hubungan dengan Group Lease / APG Group dan Mitsuji Konoshita.

Kemudian penurunan biaya kredit yang cepat menjadi alasan lain mengapa dapat terjadi pertumbuhan labayang cepat. Biaya kredit gabungan saat itu jauh di bawah rata-rata historis perusahaan.Transaksi substansial related party juga memprihatinkan. Dalam tiga bulan terakhir tahun 2016, Group Lease menghabiskan sekitar USD 90 juta untuk memperoleh saham di bisnis terkait pembiayaan di Indonesia, Sri Lanka dan Myanmar dari related party. Dan satu dari investasi ini, saham minoritas di perusahaan yang terdaftar di Sri Lanka, terjual dengan hargapremilebih besar $120 \%$ dari harga pasar yang diperdagangkan saat itu. 
Bila pendapatan Group Lease diadjust supaya biaya kredit kelihatan lebih realitis dan pendapatan bunga yang mencurigakan yang berasal related partydikeluarkan, pendapatan Group Lease turun 55\%. Dan saham Group Lease THB 22,3 per saham pun ternilai terlalu tinggi karena nilai wajarnya hanya sekitar THB 2,77 (88\% lebih rendah) (Anonymous Equity, 2017).

Orang di balik itu yaitu CEO Group Lease Mitsuji Konoshita, memiliki reputasi buruk untuk perilaku seperti itu di Jepang, di mana dia telah terkena salah satu denda regulasi terbesar yang pernah ada untuk manipulasi saham. Sekarang dia mencoba melakukan trik yang sama di Thailand, di mana investor belum sepenuhnya bijak dengan permainannya.

Tabel 1. Laba Rugi 2012 - 2016

\begin{tabular}{|c|c|c|c|c|c|}
\hline & \multicolumn{5}{|c|}{ Consolidation Financial Statement } \\
\hline & 2016 & 2015 & 2014 & 2013 & 2012 \\
\hline \multicolumn{6}{|l|}{ Revenues } \\
\hline Hire purchase interest income & 1.949.691.039 & 1.898 .441 .467 & 1.666.739.017 & 1.258.280.481 & 837.220 .599 \\
\hline Asset-backed loan interest income & 116.926 .280 & 25.484 .584 & & & \\
\hline Interest on loan receiveables & 484.858 .712 & 173.364 .647 & & & \\
\hline \multicolumn{6}{|l|}{ Other Income } \\
\hline Other interest income & 25.032 .980 & 2.202 .858 & & & \\
\hline Consulting service fee income & 63.062 .260 & 72.679 .900 & & & \\
\hline Other income related to the activities of hire pu & 218.791 .388 & 259.950 .849 & & & \\
\hline Others & 63.780 .215 & 56.578 .918 & 205.334 .694 & 213.260 .071 & 120.442 .900 \\
\hline Total Revenues & 2.922 .142 .874 & 2.488 .703 .223 & 1.872 .073 .711 & 1.471 .540 .552 & 957.663 .499 \\
\hline \multicolumn{6}{|l|}{ Expenses } \\
\hline Service and administrative expenses & 887.375 .789 & 784.371 .371 & 561.141 .506 & 362.844 .679 & 249.372 .946 \\
\hline Bad debts and doubtful accounts & 313.269 .760 & 356.566 .970 & 494.857.518 & 343.635 .227 & 45.252 .879 \\
\hline Loss on disposals of foreclosed assets & 232.251 .114 & 355.030 .334 & 431.819 .548 & 314.386 .646 & 140.250 .897 \\
\hline Total Expenses & 1.432 .896 .663 & 1.495 .968 .675 & 1.487 .818 .572 & 1.020 .866 .552 & 434.876 .722 \\
\hline \multicolumn{6}{|l|}{ Profit before share of profit from investments } \\
\hline in associates, finance cost, and income tax exp & 1.489.246.211 & 992.734 .548 & 384.255 .139 & 450.674 .000 & 522.786 .777 \\
\hline Share of profit from investments in associaties & 48.354 .685 & 0 & 0 & 0 & 0 \\
\hline Profit before finance cost and income tax & 1.537 .600 .896 & 992.734 .548 & 384.255 .139 & 450.674 .000 & 522.786 .777 \\
\hline Finance cost & -272.749 .543 & -266.768 .059 & -250.417 .641 & -145.707 .696 & -63.004 .080 \\
\hline Profit before income tax expenses & 1.264 .851 .363 & 725.966 .489 & 133.837 .498 & 304.966 .304 & 459.782 .697 \\
\hline Income tax expenses & -202.032 .098 & -143.075 .473 & -19.133 .574 & -64.652 .925 & -102.401 .329 \\
\hline Profit for the year & 1.062 .819 .265 & 582.891 .016 & 114.703 .924 & 240.313 .379 & 357.381 .368 \\
\hline
\end{tabular}

Sumber:(Annual Report GroupLease, 2012, 2014, 2015, 2016)

Sekilas, pendapatan utama Group Lease dan pertumbuhan laba tampak mengesankan. Pendapatan total terus meningkat selama 5 tahun terakhir. Bila dibandingkan dengan 10 tahun lalu (2007), pendapatannya di 2017 telah naik hampir 5x lipat (Pendapatan tahun 2007 adalah (493 juta). Namun, pada laporan keuangandibawahterlihat bahwa operasi induk di Thailand (Separate Financial Statement) telah mengalami kesulitan sejak 2014. Pendapatannya mengalami penurunan.

Tabel 2. Separate Financial Statement 2013-2016

\begin{tabular}{|crrcc|}
\hline & \multicolumn{5}{c|}{ Separate Financial Statement } \\
\hline & $\mathbf{2 0 1 6}$ & $\mathbf{2 0 1 5}$ & $\mathbf{2 0 1 4}$ & $\mathbf{2 0 1 3}$ \\
\hline Revenue & & & & \\
Other Income & 1.193 .975 .823 & 1.332 .835 .932 & 1.389 .653 .953 & 1.251 .387 .184 \\
& 610.497 .293 & 457.171 .624 & 216.717 .407 & 190.264 .303 \\
\cline { 2 - 5 } & 1.804 .473 .116 & 1.790 .007 .556 & 1.606 .371 .360 & 1.441 .651 .487 \\
\hline
\end{tabular}

Sumber: (Annual Report GroupLease, 2014, 2015, 2016)

Pertumbuhan pendapatan konsolidasi Group Lease dalam beberapa tahun terakhir lebih ke perusahaan di luar Thailand daripada perusahaan induk perusahaan Thailand. 
Selain itu, pada tahun 2016 terdapat kontribusi yang besar terhadap pertumbuhan pendapatan dari "Bunga Piutang Pinjaman" yang menyumbang 16,6\% dari total pendapatan (THB485juta). Akun ini adalah pendapatan bunga yang dihasilkan dari pinjaman berbunga tinggi kepada dua kelompok pemegang saham di Singapura dan Siprus yang ditandai oleh auditor.

Hebatnya, pertumbuhan pendapatan ini tidak menyebabkan peningkatan total biaya selama tiga tahun terakhir. Bila dilihat ke tabelnya, biaya layanan dan administrasi telah meningkat secara dramatis selama periode ini, biaya terkait kredit (yaitu biaya untuk kredit macet dan piutang tak tertagih, dan kerugian atas pelepasan aset yang diambil alih) telah turun. Ini menyebabkan total pengeluaran Group Lease tetap sama selama tiga tahun terakhir. Padahal peningkatan pendapatan atas kredit, seharusnya menambah biaya bad debts dan doubtful accounts.

Tabel 3. Biaya 2012-2016

\begin{tabular}{|c|c|c|c|c|c|}
\hline Biaya & 2016 & 2015 & 2014 & 2013 & 2012 \\
\hline Biaya servis dan administrasi & 887.375 .789 & 784.371 .371 & 561.141 .506 & 362.844 .679 & 249.372 .946 \\
\hline Biaya kredit macet dan piutang tak tertagih & 313.269 .760 & 356.566 .970 & 494.857 .518 & 343.635 .227 & 45.252 .879 \\
\hline Kerugian pelepasan aset yang diambil alih & 232.251 .114 & 355.030 .334 & 431.819 .548 & 314.386 .646 & 140.250 .897 \\
\hline Total Biaya & 1.432 .896 .663 & 1.495 .968 .675 & 1.487 .818 .572 & 1.020 .866 .552 & 434.876 .722 \\
\hline
\end{tabular}

Sumber : (Annual Report GroupLease, 2014, 2015, 2016)

Dari kasus di atas, perusahaan melakukan Shenanigans 2 yaitu menambah pendapatan melalui peminjam. Dan transaksi ini dilakukan melalui related party perusahaan serta hubungan dengan CEO Group Lease Mitsuji Konoshita dimana Mitsuji Konoshita ini pernah didenda besar oleh regulator karena melakukan kasus manipulasi pada perusahaan Jepang.

\section{KESIMPULAN}

Financial shenanigan adalah pernyataan palsu tentang status dan kinerja keuangan dalam laporan keuangan. Kecurangan keuangan dapat berupa pelanggaran kecil maupun besar yang memiliki 7 kategori shenanigan. Penelitian ini menganalisis laporan keuangan yang terdaftar di Bursa efek Thailand selama 2012-2017 dengan mengggunakan teknik shenanigans pertama, shenanigans kedua, shenanigans ketiga, shenanigans keempat, shenanigans kelima, shenanigans keenam, shenanigans ketujuh. Hasil penelitian ini menunjukkan bahwa perusahaan Group Lease tidak melakukan teknik shenanigans 1, shenanigans 2 , shenanigans 3 , shenanigans 4 , shenanigans 5 , shenanigans 6 , shenanigans 7. Group lease melakukan Teknik shenanigan 2 yaitu menambah pendapatan melalui peminjam. Perusahaan ini memanipulasi penambahan pendapatan melalui related party loans dan shell company, terjadi pengurangan provisi pinjaman yang sangat besar, CEO Group Lease saat itu, Mitsuji Konoshita pernah memiliki catatan pemanipulasian harga saham di perusahaan Wedge Holdings dan pada April 2017 didenda besar oleh regulator Jepang.

\section{KETERBATASAN}

Artikel ini masih perlu disempurnakan dan tentu saja masih banyak kekurangan yang perlu diperbaiki untuk penelitian berikutnya. Beberapa keterbatasan yang ditemukan peneliti yaitu informasi sebelumnya yang membahas kasus Group Lease di Thailand masih kurang, dan peneliti kesulitan dalam mengambil referensi artikel di Negara Thailand akibat adanya perbedaan bahasa. Peneliti harap kedepannya penelitian ini dapat dijadikan referensi peneliti selanjutnya, dan dapat menambah wawasan pembaca mengenai akuntansi internasional dan forensik. 


\section{DAFTAR PUSTAKA}

Acclime. (2021). Accounting in Thailand: Introduction. https://thailand.acclime.com/guides/accounting-introduction/

ACFE. (2020a). Report to the nations Asia Pacific Edition 2020 (Issue August).

ACFE. (2020b). Report to the nations on occupational fraud and abuse: 2020 global fraud study. Report To the Nations, 88.

Anonymous Equity. (2017). Is Group Lease A Fraud. 1-63.

Aseancpa. (2020). Thailand.

Berthelsen, J. (2017). Thai Investor Favorite, Group Lease Hit by Devastating Report.

Bloomberg. (2017). Stock.

Christian, N., Crisitiano, A., Lim, A., Maskat, U. S., \& Batam, U. I. (2021). Perkembangan akuntansi singapura serta analisis financial shenanigans pada blumont group ltd. 6(1), 84-95.

Dewanti, D. K. (2015). Studi perbandingan tingkat kepatuhan adopsi International Financial Reporting Standard (IFRS) Di 12 Negara. Diponegoro Journal of Accounting, 4(3), 245-258.

Dianitafairtale. (2017). Sejarah Perkembangan Standar Akuntansi Keuangan di Indonesia.

Dr. Wahidmurni, M. P. (2017). Pemaparan Metode Penelitian Kuantitatif.

Equity. (2017). Is Group Lease A Fraud. 1-63.

GroupLease. (2012). Annual Report 2012.

GroupLease. (2014). Annual Report 2014.

GroupLease. (2015). Annual Report 2015.

GroupLease. (2016). Annual Report 2016.

HikmaningTiyas, R. S. P. (2020). Akuntansi Internasional (Thailand).

IAI. (2020a). Ikatan Akuntan Indonesia.

IAI. (2020b). Landasan Hukum Akuntan.

IAMI. (2020). Institute manajemen akuntan indonesia.

IAPI. (2020). Institut akuntan publik indonesia.

IFAC. (2017). Federation of Accounting Professions. https://www.ifac.org/aboutifac/membership/members/federation-accounting-professions

IFRS. (2006). international Financial reporting standards.

IFRS. (2008). Interpretation and Application of International Accounting and Financial Reporting Standards 2008.

IKPI. (2020). Ikatan Konsultan Pajak Indonesia.

Kusuma, I. C., Nurfitri, R., \& Mukmin, M. N. (2019). Pengaruh Pressure, Opportunity, Rasionalization Dan Capability Terhadap Kecenderungan Kecurangan Akuntansi (Fraud). Jurnal Akunida, 5(1), 54. https://doi.org/10.30997/jakd.v5i1.1828

Mardianto, M., \& Tiono, C. (2019). Analisis Pengaruh Fraud Triangle Dalam Mendeteksi Kecurangan Laporan Keuangan. Jurnal Benefita, 1(1), 87. https://doi.org/10.22216/jbe.v1i1.3349

Nakmahachalasint, O., \& Narktabtee, K. (2018). Implementation of accrual accounting in Thailand's central government. Public Money and Management, 39(2), 139-147. https://doi.org/10.1080/09540962.2018.1478516

Natalis, C., Jessica, \& Leondy, R. (2021). Pendeteksian Financial Shenanigans Pada Laporan Keuangan PT Garuda Indonesia Tbk. 10(1), 81-87.

Nita, N. K. N., \& Supadmi, N. L. (2019). Pengaruh Pengendalian Internal, Integritas, Asimetri Informasi dan Kapabilitas Pada Kecurangan Akuntansi. E-Jurnal Akuntansi, 28(3), 1819. https://doi.org/10.24843/eja.2019.v28.i03.p12

Nugraheni, N., \& Triatmoko, H. (2017). Analisis faktor-faktor yang mempengaruhi terjadinya financial statement fraud: perspektif Diamond Fraud Theory. Jurnal 
Akuntansi Dan Auditing, III(2), 2016.

PWC. (2018). PwC's Global Economic Crime and Fraud Survey 2018 Southeast Asia Report.

Rahman, M. Z., Thomson, J. K., \& Siribuddhamas, N. (2018). Report on the Observance of Standards and Codes. In Report on the Observance of Standards and Codes. https://doi.org/10.1596/31463

Rahmawati, H. I. (2013). Pengaruh mekanisme good corporate governance (gcg) terhadap manajemen laba pada perusahaan perbankan yang terdaftar di bursa efek indonesia tahun 2009-2011.

Ratnawati, T., Salean, D., \& Maqsudi, A. (2016). Mendeteksi Kecurangan Laporan Keuangan Perusahaan. Jurnal Ekonomi \& Bisnis, 1(1), 121-132.

Rieantiari, A. W., \& Hermawan, A. A. (2020). Detecting of bond defaults indications using financial statement and shenanigans indicators. AFEBI Accounting Review (AAR), 113.

Rusmana, O., \& Tanjung, H. (2020). Identifikasi Kecurangan Laporan Keuangan Dengan Fraud Pentagon Studi Empiris Bumn Terdaftar Di Bursa Efek Indonesia. Jurnal Ekonomi, Bisnis, Dan Akuntansi, 21(4). https://doi.org/10.32424/jeba.v21i4.1545

Sakti, E., Tarjo, T., Prasetyono, P., \& Riskiyadi, M. (2020). Detection of Fraud Indications in Financial Statements Using Financial Shenanigans. Asia Pacific Fraud Journal, 5(2), 277. https://doi.org/10.21532/apfjournal.v5i2.170

Salim, S., Siswanto, H. P., Wijaya, H., \& Angela, J. (2021). Factors Affecting Financial Shenanigans in the Perspective of Fraud Triangle: An Empirical Study Among Manufacturing Companies Listed in Indonesia Stock Exchange. Proceedings of the Ninth International Conference on Entrepreneurship and Business Management (ICEBM 2020), 174(99), 420-427. https://doi.org/10.2991/aebmr.k.210507.063

Schilit, H. M. (1968). Financial Shenanigans How to Detect Accounting Gimmicks \& Fraud in Financial Reports.

Schilit, H. M. (2010). Accounting Financial-Shenanigans (pp. 1-20).

Septriyani, Y., \& Handayani, D. (2018). Mendeteksi Kecurangan Laporan Keuangan dengan Analisis Fraud Pentagon. Jurnal Akuntansi, Keuangan Dan Bisnis, 11(1), 1123.

Siallagan, H. (2016). Buku Teori Akuntansi Edisi Pertama. LPPM UHN Press, 1, 285.

Simbolon. (2010). Pengungkapan Laporan Keuangan. Akuntansi Dan Keuangan Terapan.

Space, W. L. (2014). Research methods for business. Encyclopedia of Quality of Life and Well-Being Research, 3336-3336. https://doi.org/10.1007/978-94-007-07535_102084

Udayana, E. A. U. (2017). Faktor-Faktor Yang Mempengaruhi Manajemen Laba. E-Jurnal Akuntansi, 20(1), 290-319.

Wahyuni. (2019). Deteksi Kecurangan Laporan Keuangan Oleh Kantor Akuntan Publik. Jurnal Ilmiah Akuntansi, 2(1), 41-50. 